\title{
THE EFFECT OF HEALTH PROMOTION PROGRAM FOR FAMILIES WITH ADOLESCENTS ON COMMUNICATION PATTERNS IN SLEMAN YOGYAKARTA
}

\author{
Kenik Sri Wahyuni and Bernadeta Verawati
}

Faculty of Health Sciences, Universitas Respati, Yogyakarta

\begin{abstract}
Background: Family plays an important role in shaping a person fate or destiny. Parental techniques for raising children and families training systems are amongst the most fundamental factors for a child's personality formation. An earlier study have shown a significant association between parenting style and family communication pattern with some quality of life dimensions among adolescents. This study aimed to determine the effect of health promotion program for families with adolescents on communication patterns in Sleman, Yogyakarta.

Subjects and Method: This was a comparative study conducted in several villages in Ngemplak (high exposure to PIK-R and BKR) and Kalasan (low exposure to PIK-R and BKR) sub districts, Sleman district, Yogyakarta. A total of 120 adolescents was selected for this study. The dependent variable was family communication pattern. The independent variable was Information and Counselling (PIK-R) and Adolescent Family Development (BKR) programs. The data were collected by questionnaire. The data were analyzed by univariate and bivariate.

Results: Family communication pattern was more positive in villages with high exposure of PIK-R and BKR programs than those with low exposure of PIK-R and BKR programs.

Conclusion: Family communication pattern improves with the implementation of PIK-R and BKR programs.
\end{abstract}

Keywords: communication pattern, family, BKR, PIK-R

Correspondence:

Kenik Sri Wahyuni. Faculty of Health Sciences, Universitas Respati, Yogyakarta.

Email: keniksriwahyuni@respati.ac.id.

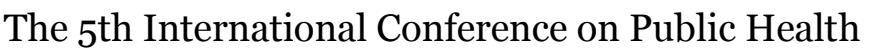
Best Western Premier Hotel, Solo, Indonesia, February 13-14, 2019 | 183 https://doi.org/10.26911/theicph.2019.02.27 